\title{
Physiological, biochemical, and molecular screening of selected upland rice (Oryza sativa L.) lines from eastern India
}

\author{
Runam Kumari, Debapriya Choudhury, Sayani Goswami and Narottam Dey*
}

\begin{abstract}
Background: Ten improved upland rice lines presently grown in dry upland rice field of Jharkhand, Odisha, and Bengal, the three most significant rice yielding states of eastern India, were screened under varying induced water stress to reveal their physiological and biochemical performance followed by rice microsatellite-based genotyping and detection of SNPs for a selected genetic loci (OSLEA3) associated with drought responses in higher plants.

Results: For physiological screening changes in plant height and external appearance of mature plant particularly greenish appearance were considered. Quantitative estimation of six biochemical compounds (chlorophyll, carotenoids, catalase, peroxidase, ascorbate peroxidase), commonly associated with normal physiological processes of plants, showed variable response under induced water stress. Variety Vandana and CRdhan 40 were identified to be the most potent drought-avoiding genotypes, whereas variety Sneha and Kalinga III showed least degree of drought tolerance for the studied screening parameters under drought. In post stressed period, both the variety Vandana and CRdhan 40 showed best performance to recover by virtue of regular water supply for a month tenure. In SSR-based genotyping, RM3825 and RM242 showed highest degree of polymorphism, whereas RM321 was monomorphic across the selected rice lines. Genomic DNA of only four lines (Vandana, Anjali, CR dhan 40, and Sahabhagidhan) were amplified with the primer pairs designed from OsLEA3 gene sequence which resulted three distinct allelic forms. Vandana and CR Dhan 40 shared a common allele of mol. wt. $1173 \mathrm{bp}$ size, whereas other two allelic forms were detected by Anjali and Sahbhagi of mol. wt. $1210 \mathrm{bp}$ and $1036 \mathrm{bp}$ respectively. A total number of 23 SNPs were detected for amplified sequence of OsLEA3 gene sequence in CR Dhan 40 of which 12 were transitions and 11 were transversions.

Conclusion: From this study, it could be concluded that var. CR Dhan 40, Vandana, and Sahabhagidhan performed better, both physiologically and biochemically under induced drought stress.
\end{abstract}

Keywords: Upland rice, Drought tolerance, Rice microsatellite, SSR markers, Allelic diversity, SNP

\section{Introduction}

As per ICRISAT-WWWF Project (2009), rice cultivation is the highest water-consuming process as it needs about $3000-5000 \mathrm{~L}$ of water for production of $1 \mathrm{~kg}$ of rice. Being one of the single biggest users of freshwater for rice cultivation, Asia consumes more than $40 \%$ of the worlds' freshwater for irrigated rice cultivation (Gleick et al. 2002; Abdallah et al. 2016). Tuong and Bouman (2003) estimated that, by 2025 , approximately 2 million hectares of irrigated

\footnotetext{
*Correspondence: narottam.dey@visva-bharati.ac.in

Department of Biotechnology, Visva-Bharati, Santiniketan 731235, India
}

dry season rice system and 13 million hectares of wet-season rice system will experience water scarcity. Nowadays, it became essential to practice the cultivation of upland rice lines which are highly drought tolerant and able to grow in adverse heterogeneous environment due to lack of sufficient rainfall and avoidance of over-exploitation of ground water. For popularization of such upland rice lines, a number of early flowering drought-tolerant rice lines have been released by ICAR-NRRI, the premier research institute of eastern India.

The objective of this present investigation was selection of the best performing rice genotype, suitable for 
dry upland rice field of eastern India through a number of common experiments which included (i) physiological and biochemical screening under varying induced water stresses, (ii) genotyping of the studied lines with nine drought tolerance linked SSR markers, and (iii) identification of the variation of DNA sequence amplified from the gene, OsLEA, for the best performed genotype considering IRGSP sequence as reference sequence.

\section{Materials and methods}

Ten upland rice lines commonly grown as the most popular lines in dry upland rice field of Jharkhand, Odisha, and Bengal were selected for the present study. The selected lines were collected from Central Rainfed Upland Rice Research Station (CRURRS) Hazaribagh (Jhanrkhand), India, which is the upland regional research station of ICAR-NRRI, Cuttack (Indian Council of Agricultural Research-National Rice Research Institute, Cuttack), where a good number of upland drought-tolerant rice lines are maintained and experimented for their possible utilization in breeding. The geographic location of CRURRS is shown within India in Fig. 1. All the rice lines were maintained in
University experimental fields with our own accession number in addition to IRGC number for better management, representation, and identification and is presented in Table 1.

\section{Agromorphological characterization}

Each lines were grown in normal growth condition and primarily characterized for a few most common agromorphological traits (days to flowering, flag leaf length, panicle length, number of spikelets/panicle, grains/panicle, grain shape, and 100 grain weight).

\section{Physiological screening under induced water stress}

Physiological screening for drought response was done in small earthen pot of $15 \mathrm{~cm}$ diameter and $16 \mathrm{~cm}$ height. For each line, four pots were prepared with equal amount of rice field soil mixed with natural composed fertilizers and in each pot four plants were established through direct sowing. Drought was induced through direct withdrawal of water from the soil for a fixed duration followed by regular supply of water for 1 month duration as recovery period. Six-week-old healthy young plants were water stressed for 2 days, 4 days, and 6 days and designated as $\mathrm{T} 1, \mathrm{~T} 2$, and $\mathrm{T} 3$ respectively following

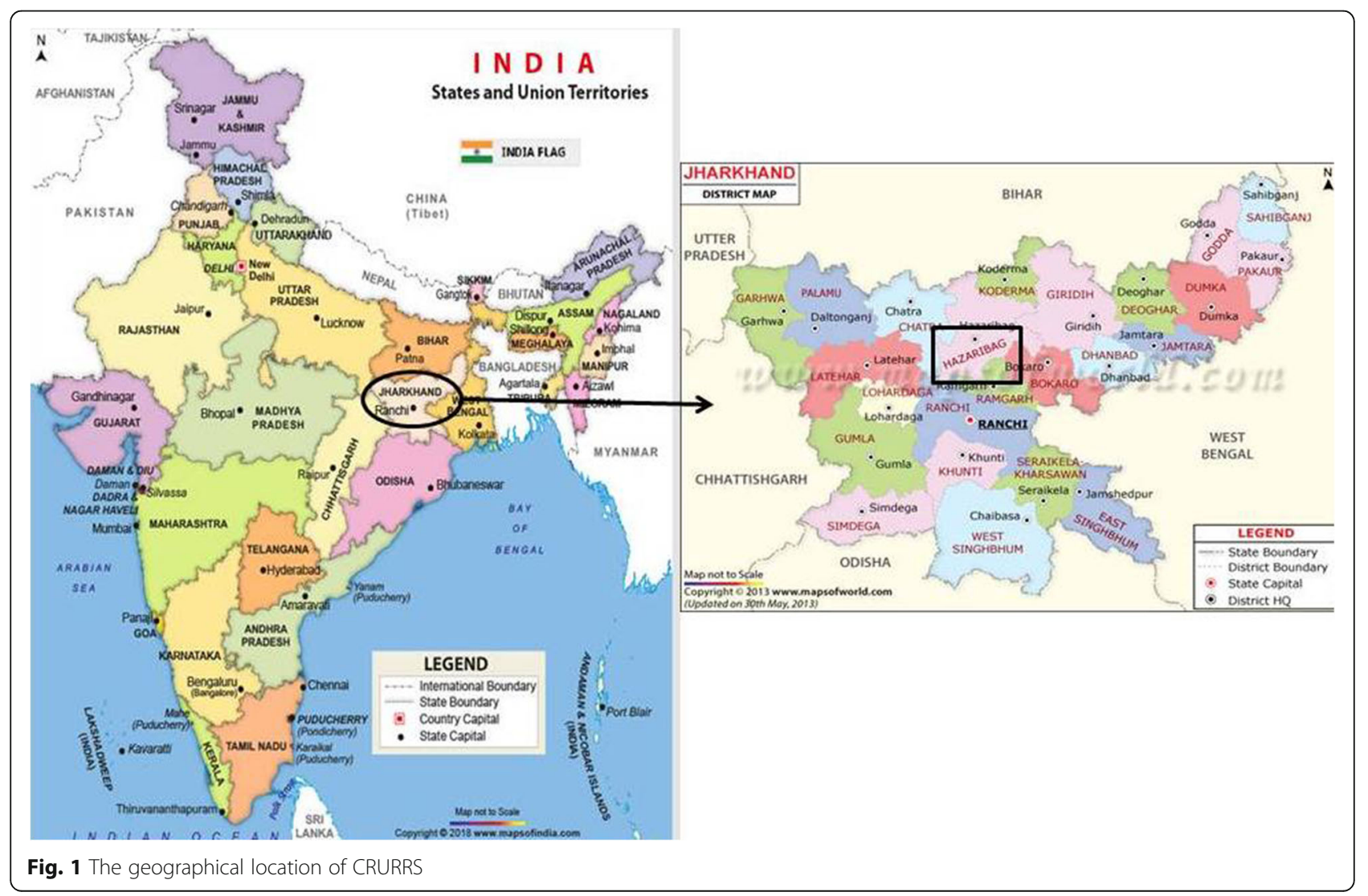


Table 1 Details of rice lines used in present study

\begin{tabular}{|c|c|c|c|c|}
\hline $\begin{array}{l}\text { Sl. } \\
\text { No. }\end{array}$ & Variety & $\begin{array}{l}\text { Visva-Bharati } \\
\text { Acc. No. }\end{array}$ & $\begin{array}{l}\text { Flowering } \\
\text { duration } \\
\text { (in days) }\end{array}$ & Specific note \\
\hline 1 & Vandana & VB33 & 90 & $\begin{array}{l}\text { Upland rainfed, } \\
\text { drought tolerant }\end{array}$ \\
\hline 2 & Anjali & VB459 & 95 & Upland rice \\
\hline 3 & Virendra & VB460 & 90 & $\begin{array}{l}\text { Upland, resistance } \\
\text { to gall midge blast }\end{array}$ \\
\hline 4 & CR Dhan 40 & VB461 & 110 & $\begin{array}{l}\text { Upland rice, resistant } \\
\text { to brown spot, blast }\end{array}$ \\
\hline 5 & $\begin{array}{l}\text { Sahbhagi } \\
\text { dhan }\end{array}$ & VB462 & 105 & Upland rice \\
\hline 6 & Abhishek & VB463 & 125 & Irrigated \\
\hline 7 & IR64 Drt 1 & VB464 & 120 & $\begin{array}{l}\text { Deep rooted } \\
\text { drought resistance }\end{array}$ \\
\hline 8 & CR dhan 103 & VB465 & 89 & Upland \\
\hline 9 & Sneha & VB466 & 68 & Upland \\
\hline 10 & Kalinga III & VB467 & 80 & Upland \\
\hline
\end{tabular}

published report (Chan et al. 2012) after little modification. For each line, a control set was maintained, where pots were regularly watered and recorded regularly on the same days interval like treatment set and designated as $\mathrm{C} 1, \mathrm{C} 2$, and $\mathrm{C} 3$ respectively. The whole sets of experimental plants were maintained in the same environmental condition within glass house. Each treated lines, after completion of respective duration water with drawl, saturated with water regularly for 1 month duration as recovery period. The soil moisture content of each plot was monitored accordingly and adjusted with help of a soil moisture meter (Lutron, PMS-714) and presented in Table 2. The whole experiment was conducted in the month of April-May, 2016 and average temperature was recorded as $38-42{ }^{\circ} \mathrm{C}$ and $26-28{ }^{\circ} \mathrm{C}$ during day and night time, respectively. Experimental set up for screening and external morphology of a single representative plant under induced drought is presented in Fig. 2.

\section{Physiological screening}

Plant height of both control $(\mathrm{C} 1, \mathrm{C} 2, \mathrm{C} 3)$ and test (T1, T2, T3) lines were recorded and plotted graphically in pair for each individual lines.

\section{Biochemical estimation for selected compounds}

Five biochemical compounds (chlorophyll, carotenoids, catalase, peroxidase, ascorbate peroxidase contents) were estimated to determine their variable availability in normal and stressed plants. Total chlorophyll and carotenoid contents were estimated by standard protocols (Arnon 1949; Talcott and Howard 1999).
Table 2 Moisture content throughout whole experiment in percentile method

\begin{tabular}{llllll}
\hline Variety & C (\%) & T1 (\%) & T2 (\%) & T3 (\%) & Recovery (\%) \\
\hline VB33 & 49.9 & 23.6 & 13.7 & 6.4 & 51 \\
VB459 & 48.9 & 21.8 & 12.8 & 6.1 & 49.6 \\
VB460 & 49.9 & 21.3 & 12.6 & 5.8 & 48 \\
VB461 & 47.5 & 26.6 & 14.9 & 6.5 & 49.5 \\
VB462 & 47 & 20 & 11.9 & 4.7 & 50.2 \\
VB463 & 48.4 & 20.1 & 17.6 & 6.7 & 47.9 \\
VB464 & 49.9 & 25.7 & 14.5 & 5.6 & 48.3 \\
VB465 & 45.3 & 23.3 & 16.8 & 7 & 49.0 \\
VB466 & 43.7 & 20.6 & 15.5 & 5.1 & 52 \\
VB467 & 45.7 & 21.4 & 15.4 & 8.7 & 51.6 \\
\hline
\end{tabular}

Where $\mathrm{C}=$ moisture content before the beginning of experiment or in control conditions or zero day, $\mathrm{T} 1=$ moisture content after 2 days of induced drought, $\mathrm{T} 2$ = moisture content after 4 days of induced drought, $\mathrm{T} 3=$ moisture content after 6 days of induced drought

Three antioxidative enzymes (catalase, peroxidase, and ascorbate peroxidase) were quantitatively estimated following the standardized protocols (Snell and Snell 1971; Biswas and Choudhuri 1978; Chance and Maehly 1955; Kar and Mishra 1976; Nakano and Asada 1981). At recovery test, during post-stressed period, regular supply of water was done for 30 days and after completion of a month tenure, all the five biochemical compounds were estimated both in recovered plants and respective control plants of individual lines.

\section{Genotyping \\ Marker-based screening}

Genomic DNA of the studied rice lines was isolated following a pre-standardized protocol (Roychowdhury et al. 2012) of our laboratory. Nine microsatellite loci earlier reported (Lin et al. 2007; Kamoshita et al. 2008; Chen et al. 2011; Lang et al. 2013; Noorzuraini et al. 2013) to be linked with differential drought responses were selected for genotyping. The detailed information of the selected loci is presented in Table 3. Sequence information of the selected SSR loci were retrieved from Gramene database (http:// www.gramene.org/), a comparative web data resource for cereal crops. Basic Local Alignment Search Tool (BLAST) in Gramene (http://www.gramene.org/) was done to confirm the complementarity of primer sequences of the selected SSR loci markers in rice genome. PCR amplification was performed in $25 \mu \mathrm{l}$ of reaction mixture following our earlier reported work (Goswami et al. 2015). Annealing temperature was changed according to the melting temperature (Tm) value of different primer pairs and the amplified products were resolved through $1.5 \%$ agarose gel. The 


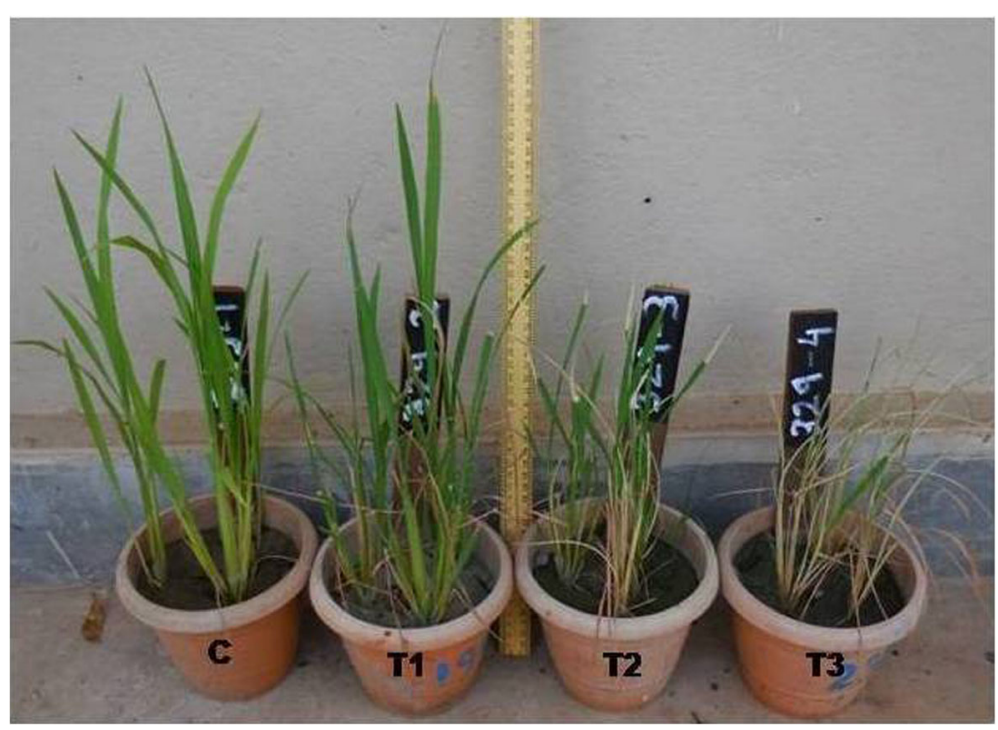

Fig. 2 Representative image of the experimental set up for physiological screening under induced drought stress

molecular weight (in bp) of the amplified products for the different studied SSR markers was determined using gel analysis software (AlphaEaseFC 4.0, USA). Individual alleles (variation in molecular weight of amplified product for individual primer pairs) for the SSR markers were scored to prepare a $1 / 0$ matrix based on presence (1) and absence (0). A dendrogram was constructed using complete linkage between groups using $\mathrm{R}$, a statistical programming software. Polymorphism information content (PIC) values for each SSR marker were calculated using a simplified formula (Hwang et al. 2009).

\section{Sequence diversity analysis and detection of SNPs for rice} LEA gene

Rice late embryogenesis abundant gene (OsLEA3), functioning under differential osmotic stresses (Duan and Cai 2012), were subjected to amplify with the genomic DNA of studied lines to find out the sequence variation in respect to reference sequence

Table 3 Detailed information of the primers used for genotyping

\begin{tabular}{|c|c|c|c|c|c|c|}
\hline \multirow[t]{2}{*}{ Name of SSR marker } & \multicolumn{2}{|l|}{ Nucleotide sequence } & \multirow{2}{*}{$\begin{array}{l}\text { Chromosome } \\
\text { NO. }\end{array}$} & \multirow{2}{*}{$\begin{array}{l}\text { Repeat } \\
\text { motif }\end{array}$} & \multirow{2}{*}{$\begin{array}{l}\text { Anneal } \\
\text { temp }\left({ }^{\circ} \mathrm{C}\right)\end{array}$} & \multirow{2}{*}{$\begin{array}{l}\text { Expected product } \\
\text { size (bp) }\end{array}$} \\
\hline & $\begin{array}{l}\text { Forward primer } \\
\left(5^{\prime} \text { to } 3^{\prime}\right)\end{array}$ & $\begin{array}{l}\text { Reverse primer } \\
\left(5^{\prime} \text { to } 3^{\prime}\right)\end{array}$ & & & & \\
\hline RM107 & AGATCGAAGCATCGCGCCCGA & ACTGCGTCCTCTGGGTTCCCGG & 9 & $(G A) 7$ & 67 & 189 \\
\hline RM242 & GGCCAACGTGTGTATGTCTC & TATATGCCAAGACGGATGGG & 9 & $(\mathrm{CT}) 26$ & 55 & 225 \\
\hline RM3825 & AAAGCCCCCAAAAGCGGTAC & GTGAAACTCTGGGGTGTTCG & 1 & $(G A) 21$ & 55 & 147 \\
\hline RM271 & TCAGATCTACAATTCCATCC & TCGGTGAGACCTAGAGAGCC & 10 & $(G A) 15$ & 55 & 101 \\
\hline RM136 & GAGAGCTCAGCTGCTGCCTCTAGC & GAGGAGCGCCACGGTGTACGC & 6 & $(A G G) 7$ & 55 & 101 \\
\hline RM5443 & TACGGCTTACCCATAGCAGC & AAACGGAGGGAGTATTTCCC & 1 & (TC) 17 & 50 & 147 \\
\hline RM321 & CCAACACTGCCACTCTGTTC & GAGGATGGACACCTTGATCG & 9 & (CAT)5 & 55 & 200 \\
\hline RM553 & AACTCCACATGATTCCACCC & GAGAAGGTGGTTGCCAGAAGC & 9 & $(\mathrm{CT}) 10$ & 55 & 162 \\
\hline OSR28 & AGCAGCTATAGCTTAGCTGG & ACTGCACATGAGCAGAGACA & 9 & $(A G A) n$ & 55 & 150 \\
\hline \multicolumn{7}{|l|}{$\begin{array}{l}\text { Details of the primer } \\
\text { pairs specifically lined } \\
\text { to LEA genetic locus }\end{array}$} \\
\hline Marker name & Forward primer & Reverse primer & Chr. No. & $\operatorname{Tm}\left({ }^{\circ} \mathrm{C}\right)$ & \multicolumn{2}{|c|}{ Expected product size (bp) } \\
\hline LEA & 5'GCTTAGGATCAATGGCTTCCCACC3 ' & $\begin{array}{l}\text { 5'CCAAAGGGAAATCATTCAC } \\
\text { GGCGTC3' }\end{array}$ & & 59 & \multicolumn{2}{|l|}{900} \\
\hline
\end{tabular}


available IRGSP database. The detailed information of the used primer pair is presented in Table 3.

\section{Results}

The morphology of grain and kernel of each studied lines are presented in Fig. 3. It has been seen that most grains are slender in shape, and medium shaped grain is found in IR64drt and CRdhan 103. Abhisek has bold grain. The detailed agromorphological characterization with specific note is presented in Table 4. This information is very much significant for ready identification of individual lines with little information on growth behavior.

The experimental set up and effect of differential drought stress on external morphology of single plants is presented in Fig. 2, which showed full greenish coloration in control plant which gradually reduces in $\mathrm{T} 1$ and $\mathrm{T} 2$, and in $\mathrm{T} 3$ the leaves gradually dried into straw. Leaf rolling was first started in T1 plants and completely rolled in $\mathrm{T} 3$ plants and finally dried into straw. To compare the plant height between control and test plants of different stages across the studied lines, pairwise comparison of the mean values were tested through Duncan's multiple range test (DMRT) in SPSS 16.0 and the plant height of the studied lines are graphically presented in Fig. 4 where different groups are presented by letters a, b, c, d, etc. All the ten rice lines showed drought tolerance capacity up to a moderate drought stress in the present experiment.

Varied accumulation of studied biochemical compounds (chlorophyll, carotenoid, catalase, peroxidase, and ascorbate peroxidase) in control and test lines during drought and in recovery phase are presented in Fig. 5a-f, respectively. Pairwise comparisons of the mean values were tested through DMRT as mentioned earlier presented by different letters. At the highest stressed condition with respect to its control set, CRdhan 40 showed best performance for chlorophyll content, carotenoid content, catalase, and peroxidase activity which were $10.51 \mathrm{mg} / \mathrm{g}, 2.52 \mathrm{mg} /$ g, $17.07 \mathrm{unit} / \mathrm{min} / \mathrm{g}$ fresh wt., and $155.98 \mathrm{unit} / \mathrm{min} / \mathrm{g}$ fresh wt, respectively (Fig. 5a-d). Var. Anjali showed high catalase activity (9.22 unit/min/g fr.wt.) under highest stressed condition in respect of its same aged control set. Var. Vandana was the best accumulator of carotenoid $(2.23 \mathrm{mg} / \mathrm{g}$ fr. wt), whereas CRdhan 103 was the least accumulator of ascorbate peroxidase $(0.31 \mathrm{unit} / \mathrm{min} / \mathrm{g}$ fr. wt. $)$ at $\mathrm{T} 3$. Under induced stress, Kalinga III did not show any remarkable accumulation of biochemical compounds except ascorbate peroxidase (Fig. 5e) to overcome drought but the level of ascorbate peroxidase was not enough to survive it under severe stress. The different biochemical compounds estimated were analyzed through simple pair $t$ test using SPASS 16.0 to test the significance of mean difference of individual stressed plant with its same aged control set at the level of $P<0.05$. At recovery test, during post-stressed period with regular supply of water for a month, except Sneha and Kalinga III, all were recovered but rate of recovery were least in case of CRdhan 103. Promisingly, Vandana, CRdhan 40 showed best performance both in drought tolerance and degree of recovery (Fig. 5f). The different allelic forms in terms of variation in mol. wt. of amplified products for individual SSR loci across the studied lines are presented in a microsatellite panel (Table 5). The SSR loci RM242 and RM3825 produced

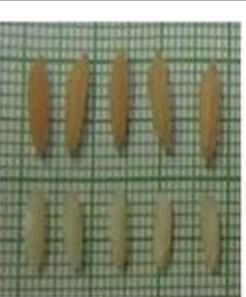

Vandana

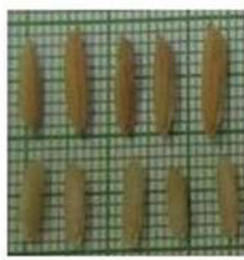

Abhishek

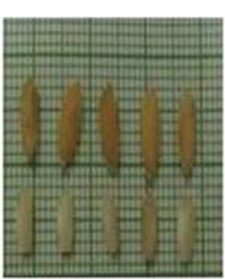

Anjali

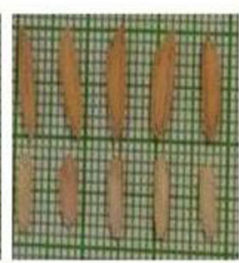

IR64 Drt 1

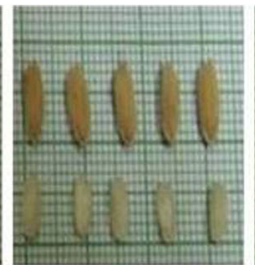

Virendra

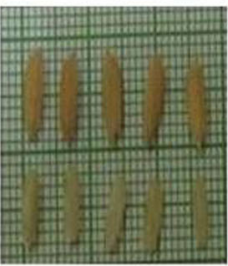

CR dhan 103
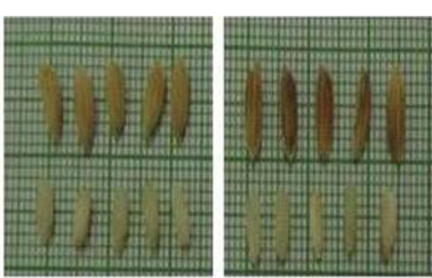

CR Dhan 40

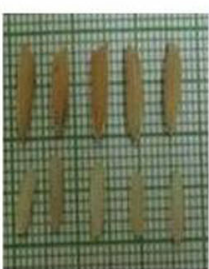

Sneha

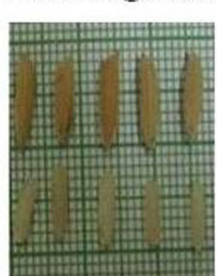

Kalinga III

Fig. 3 Grain and kernel morphology of the studied rice lines 
Table 4 Agromorphological characterization of rice lines used in present study

\begin{tabular}{|c|c|c|c|c|c|c|c|}
\hline SI. No. & Variety name & $\begin{array}{l}\text { Panicle length } \\
(\mathrm{cm})\end{array}$ & $\begin{array}{l}\text { Flag leaf } \\
\text { length }(\mathrm{cm})\end{array}$ & $\begin{array}{l}\text { Spikelet/ } \\
\text { panicle }\end{array}$ & $\begin{array}{l}\text { Grain/ } \\
\text { panicle }\end{array}$ & $\begin{array}{l}100 \text { seeds } \\
\text { weight }(\mathrm{g})\end{array}$ & $\begin{array}{l}\text { Grain shape } \\
\text { length/breadth }\end{array}$ \\
\hline 1 & Vandana (VB33) & 19.3 & 34.8 & 20 & 109 & 2.4 & 3.8 (SL) \\
\hline 2 & Anjali (VB459) & 22.3 & 34.1 & 18 & 110 & 2.3 & $3.6(S L)$ \\
\hline 3 & Virendra (VB460) & 25.8 & 31.3 & 40 & 188 & 2.53 & $4.5(S L)$ \\
\hline 4 & $\begin{array}{l}\text { CR Dhan } \\
40 \text { (VB461) }\end{array}$ & 18.1 & 23.9 & 13 & 95 & 1.92 & $4.0(S L)$ \\
\hline 5 & $\begin{array}{l}\text { Sahbhagi } \\
\text { dhan (VB462) }\end{array}$ & 21.4 & 34.1 & 12 & 120 & 1.84 & $3.8(\mathrm{SL})$ \\
\hline 6 & Abhishek (VB463) & 21.4 & 31.8 & 19 & 138 & 2.1 & $2.8(B)$ \\
\hline 7 & $\begin{array}{l}\text { IR64 Drt } 1 \\
\text { (VB464) }\end{array}$ & 18.2 & 27.6 & 12 & 86 & 2.5 & $3.3(\mathrm{M})$ \\
\hline 8 & $\begin{array}{l}\text { CR dhan } \\
103 \text { (VB465) }\end{array}$ & 16.7 & 25.3 & 33 & 151 & 2.03 & $3.3(\mathrm{M})$ \\
\hline 9 & $\begin{array}{l}\text { Sneha } \\
\text { (VB466) }\end{array}$ & 14.2 & 21.8 & 18 & 76 & 2.18 & $4.8(S L)$ \\
\hline 10 & $\begin{array}{l}\text { Kalinga III } \\
\text { (VB467) }\end{array}$ & 21.1 & 29.6 & 13 & 75 & 2.0 & $4.6(S L)$ \\
\hline
\end{tabular}

$S L$ slender, $M$ medium, $B$ bold as per SES for grain shape where $>3.55$,

$2.87-3.55,2.47-2.86,<2.47$ indicated as slender, medium, bold, round shape respectively)

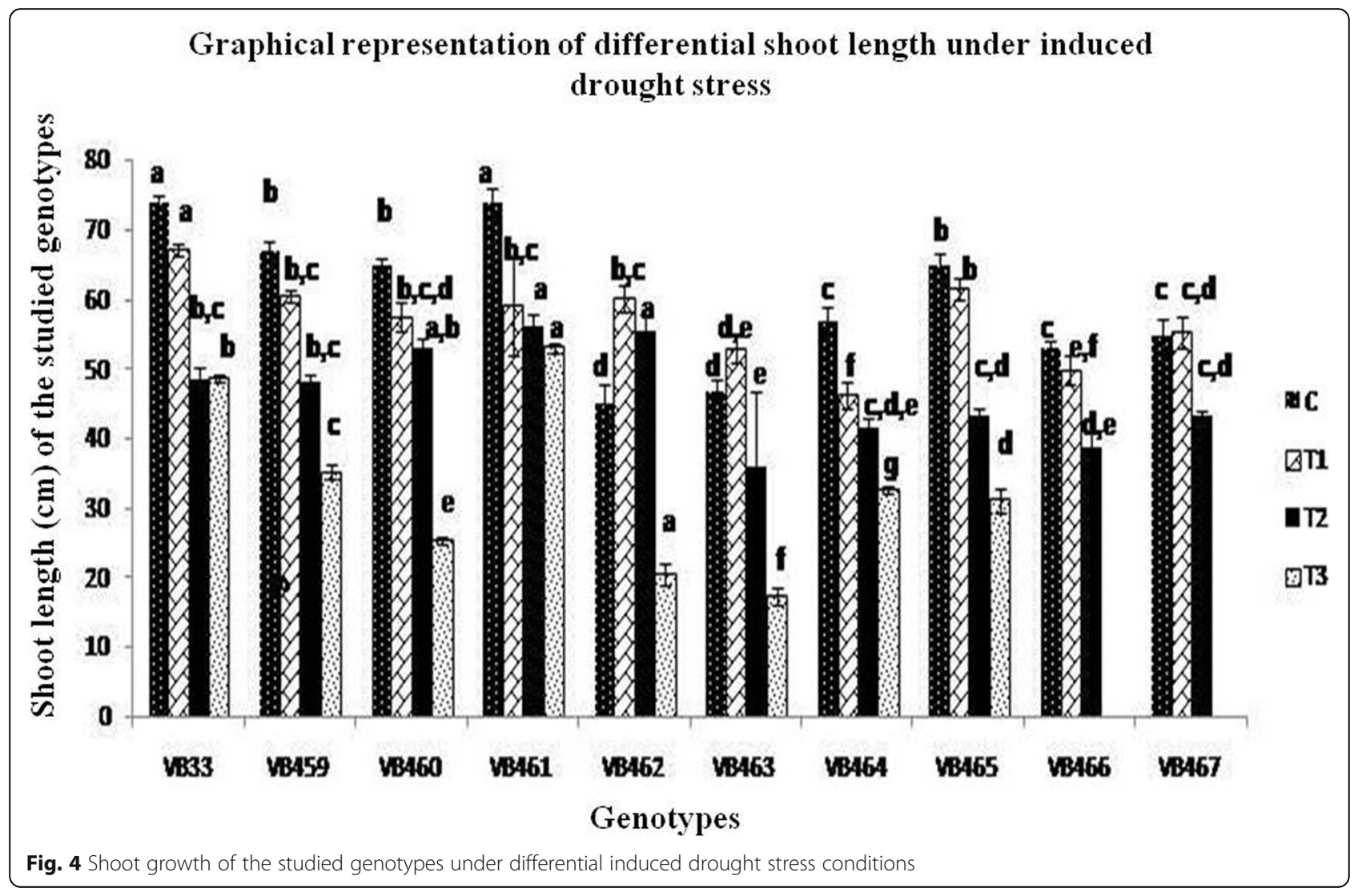




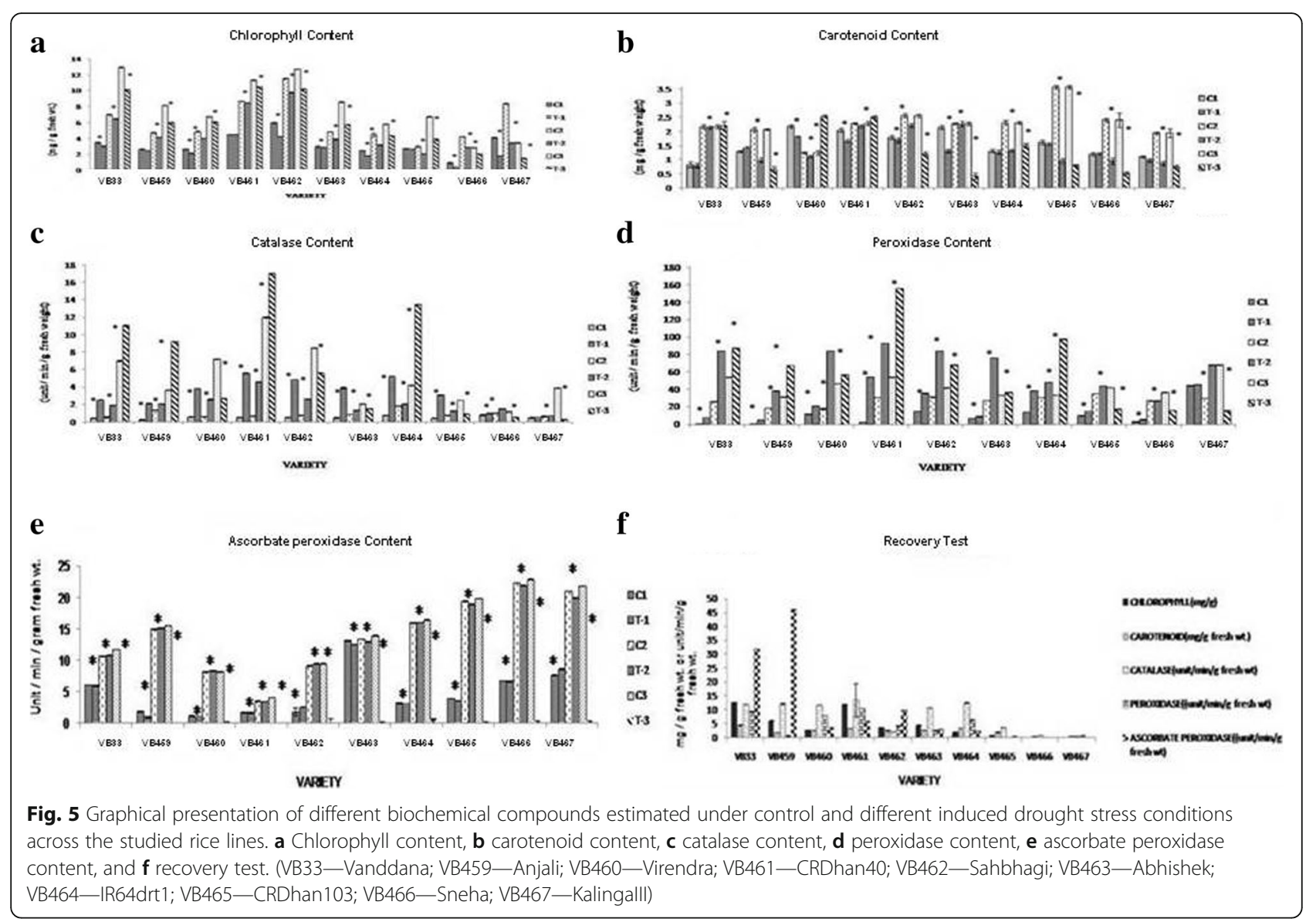

maximum (six) allele while only one allele (monomorphic) was generated for RM321 across the studied ten rice lines and the highest amplified product (225 bp) is represented by RM242. The polymorphism content value (PIC value) of individual SSR loci across the studied genotypes were calculated and presented in Table 6. A 1/0 matrix of the studied ten rice lines for nine SSR markers was created on the basis of the presence (1) and absence (0) of a specific band which was further used to prepare a similarity matrix and construction of a dendrogram (Fig. 6) using $\mathrm{R}$ Program. In derived dendrogram,

Table 5 Microsatellite panel of studied rice lines against used nine SSR markers

\begin{tabular}{|c|c|c|c|c|c|c|c|c|c|c|}
\hline \multirow{2}{*}{$\begin{array}{c}\text { SSR } \\
\text { MARKER }\end{array}$} & \multicolumn{10}{|c|}{ MOLECULAR WEIGHT OF 10 DIFERENT RICE LINES } \\
\cline { 2 - 12 } & VB33 & VB459 & VB460 & VB461 & VB462 & VB463 & VB464 & VB465 & VB466 & VB467 \\
\hline RM107 & 252 & 252 & 252 & 259 & 252 & 252 & 252 & 252 & 252 & 252 \\
\hline RM242 & 197 & 197 & 197 & 177 & 220 & 210 & 229 & 197 & 215 & 215 \\
\hline RM136 & 103 & 94 & 94 & 94 & 103 & 103 & 94 & 94 & 103 & 103 \\
\hline RM553 & 139 & 139 & 145 & 145 & 133 & 145 & 133 & 142 & 159 & 159 \\
\hline RM5443 & 144 & 131 & 138 & 151 & 151 & 138 & 131 & 158 & 138 & 131 \\
\hline RM321 & 156 & 156 & 156 & 156 & 156 & 156 & 156 & 156 & 156 & 156 \\
\hline RM271 & 117 & 117 & 117 & 117 & 112 & 118 & 118 & 117 & 117 & 109 \\
\hline RM3825 & 131 & 158 & 158 & 152 & 147 & 147 & 170 & 147 & 167 & 167 \\
\hline RMOSR28 & 149 & 145 & 149 & 149 & 149 & 149 & 149 & 149 & 145 & 149 \\
\hline
\end{tabular}

$\square$ Allele $A_{,} \square$ allele $B_{1} \square$ allele $C_{1} \square$ allele $D_{,} \square$ unique allele


Table 6 PIC values of studied SSR markers

\begin{tabular}{lll}
\hline SI. No. & Name of SSR marker & PIC value \\
\hline 1 & RM107 & 0.18 \\
2 & RM242 & 0.82 \\
3 & RM3825 & 0.8 \\
4 & RM271 & 0.58 \\
5 & RM136 & 0.5 \\
6 & RM5443 & 0.76 \\
7 & RM321 & 0 \\
8 & RM553 & 0.78 \\
9 & OSR28 & 0.32 \\
\hline
\end{tabular}

two major clusters were generated of which the first one was shared by Sahbhagidhan, Abhishek, IR64 Drt 1, CRdhan 103 and the second cluster has included two sub clusters. The first sub cluster included Sneha and Kalinga and in the second sub cluster Anjali and Virendra produce a small cluster which again share with Vandana to form another cluster which again share with CR Dhan 40. In LEA gene-specific genotyping, Vandana and CR Dhan 40 shared a common allele of $1173 \mathrm{bp}$. Another two different allelic forms of this gene were recorded from Anjali and Sahabhagi of molecular weight $1210 \mathrm{bp}$ and $1036 \mathrm{bp}$ respectively and is presented in Table 7. Twenty-three local SNPs were detected from the best tolerant line CRdhan 40 through aligning the amplified DNA sequence (for LEA gene) with the LEA gene sequence of reference genome
Table 7 Comparison between expected product size and experimental product size of the alleles of LEA gene

\begin{tabular}{llll}
\hline SI. & $\begin{array}{l}\text { Name of RM } \\
\text { markers }\end{array}$ & $\begin{array}{l}\text { Expected } \\
\text { product size }\end{array}$ & $\begin{array}{l}\text { Allelic forms } \\
\text { of LEA }\end{array}$ \\
\hline 1 & VB33 & $900 \mathrm{bp}$ & $1173 \mathrm{bp}$ \\
2 & VB325 & & $1210 \mathrm{bp}$ \\
3 & VB327 & $1173 \mathrm{bp}$ \\
4 & VB328 & $1036 \mathrm{bp}$ \\
\hline
\end{tabular}

from IRGSP (Table 8) of which 12 were transitions and 11 were transversions.

\section{Discussion}

Of the different abiotic stresses, drought is the most significant constrain for rice yield stability. Cultivation of rice with less water is the global issue across all rice growing countries including India. In this regards, cultivation and popularization of upland rice more specifically aerobic rice is the prime solution. Almost all rice growing countries including China has developed some aerobic rice lines which are being cultivated in upland rice fields. In this present study, all the rice lines investigated are from dry upland areas where there is no irrigation facility and solely depend on availability rain water. Upland and aerobic rice lines maintained their growth and performance under limited water condition by virtue of a number of morphological, physiological, and biochemical adaptation, the study of which are significant for upland rice breeding programme. In addition to these screening with drought tolerance linked molecular

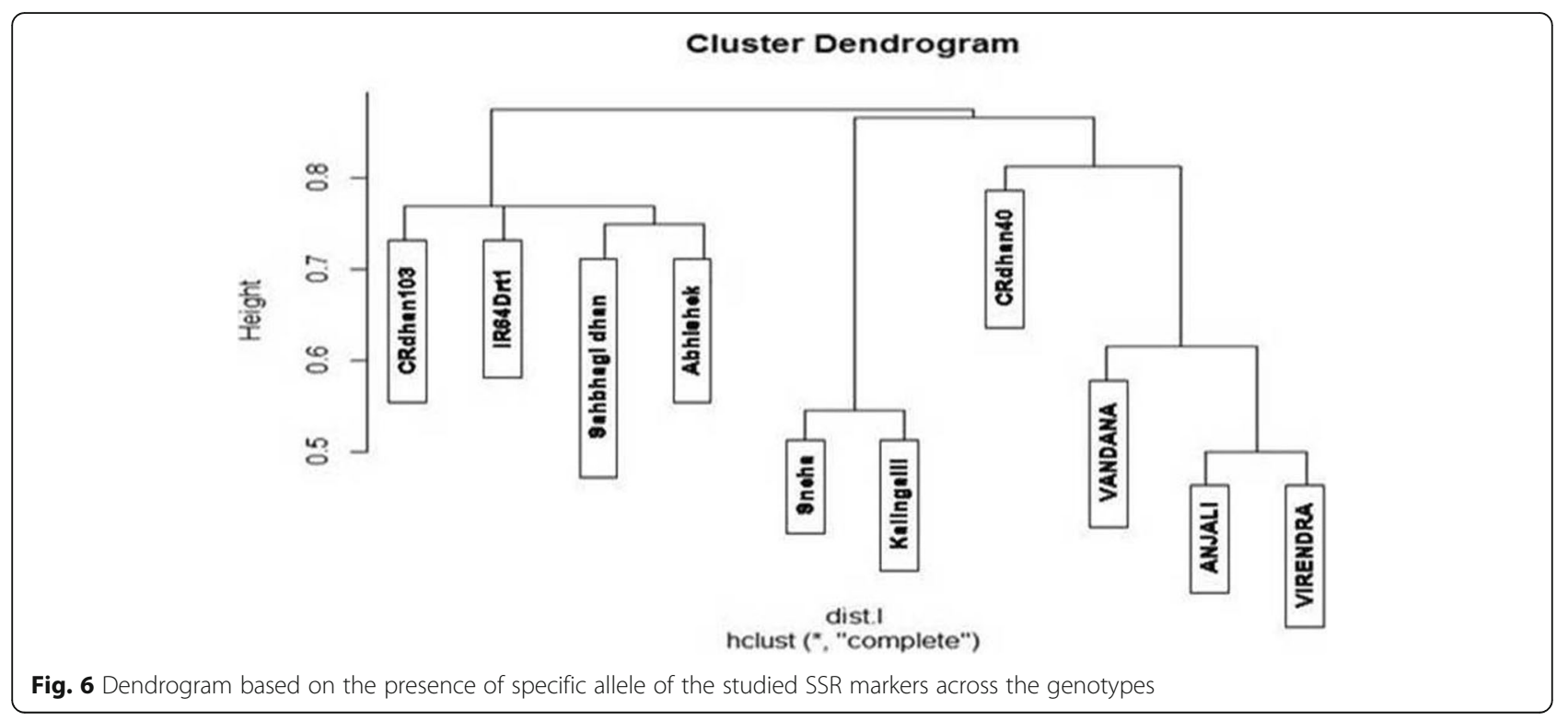


Table 8 SNPs detected in tolerant genotype CRdhan40 in respect of IRGSP reference genome sequence

\begin{tabular}{|c|c|c|c|}
\hline $\begin{array}{l}\text { Position } \\
\text { No. }\end{array}$ & $\begin{array}{l}\text { Nucleotide in reference } \\
\text { genome }\end{array}$ & $\begin{array}{l}\text { Nucleotide in CRdhan } 40 \\
\text { genome }\end{array}$ & Type \\
\hline 271 & $A$ & $G$ & tn \\
\hline 277 & $\mathrm{~T}$ & $\mathrm{G}$ & TV \\
\hline 528 & $A$ & $\mathrm{~T}$ & TV \\
\hline 536 & C & A & TV \\
\hline 537 & $\mathrm{G}$ & A & tn \\
\hline 541 & G & A & tran \\
\hline 552 & $A$ & C & TV \\
\hline 579 & G & A & $\tan n$ \\
\hline 585 & G & A & tran \\
\hline 586 & $\mathrm{~T}$ & A & TV \\
\hline 601 & G & C & TV \\
\hline 627 & G & $\mathrm{T}$ & TV \\
\hline 632 & $T$ & C & $\operatorname{Trn}$ \\
\hline 636 & C & $\mathrm{T}$ & tran \\
\hline 645 & A & C & TV \\
\hline 668 & G & A & $\operatorname{Trn}$ \\
\hline 673 & G & $\mathrm{T}$ & TV \\
\hline 687 & A & G & $\operatorname{Trn}$ \\
\hline 691 & G & $A$ & $\operatorname{Trn}$ \\
\hline 697 & G & C & TV \\
\hline 706 & G & A & $\operatorname{Trn}$ \\
\hline 708 & G & A & $\operatorname{Trn}$ \\
\hline 710 & A & $C$ & TV \\
\hline
\end{tabular}

markers and identification of different allelic forms of vital genes like DREB, LEA, CALMOD are essential for molecular breeding programme.

\section{Conclusion}

All the different parameters mentioned are attempted to include in this present study for choosing suitable lines for upland rice breeding programme. In the present study throughout the whole experiment, three studied lines, CR Dhan 40, Vandana, and Sahabhagidhan, performed better in both physiological and biochemical performance under induced drought.

\section{Acknowledgements}

The work was financial supported by the Department of Biotechnology, Govt. of India, and Departments of Science and Technology, Govt. of India. The fellowship of RK was provided by DBT, Govt. of India and fellowship of DC and SG was provided by Department of Science and Technology as DSTINSPIRE fellowship, Govt. of India; all the infrastructure was provided by Visva-Bharati.

\section{Funding}

The work was financial supported by the Department of Biotechnology, Govt. of India, and Departments of Science and Technology, Govt. of India.
The fellowship of RK was provided by DBT, Govt. of India and fellowship of DC and SG was provided by Department of Science and Technology as DSTINSPIRE fellowship, Govt. of India; all the infrastructure was provided by Visva-Bharati.

\section{Availability of data and materials}

This is an original research work done within the premises of Visva-Bharati, Santiniketan and all the data are obtained from the experiments done.

\section{Authors' contributions}

Physiological, biochemical, and molecular analysis was done by RK and DC. Drafting, editing, and revision of the manuscript were done by SG and ND. All authors read and approved the final manuscript.

\section{Ethics approval and consent to participate}

All the authors consent to participate in any matter related to the paper and journal.

\section{Consent for publication}

Not applicable.

\section{Competing interests}

The authors declare that they have no competing interests.

\section{Publisher's Note}

Springer Nature remains neutral with regard to jurisdictional claims in published maps and institutional affiliations.

Received: 18 July 2018 Accepted: 12 March 2019

Published online: 03 April 2019

\section{References}

Abdallah EH, Musa Y, Mustafa M, Sjahril R, Riadi M (2016) Comparison between hydro and osmo-priming to determine period needed for priming indicator and its effect on germination percentage of aerobic rice cultivars (Oryza sativa L.). AGRIVITA J Agri Sci 38(3):222-230

Arnon DI (1949) Copper enzymes in isolated chloroplasts.polyphenoloxidase in Beta vulgaris. Plant Physiol 24(1):1-15

Biswas AK, Choudhuri MA (1978) Differential behaviour of the flag leaf of intact rice plant during ageing. Biochem Physiol Pflanz 173:220-228

Chan CS, Zainudin H, Saad A, Azmi M (2012) Productive water use in aerobic rice cultivation. J Trop Agri Fd Sc 49(1):117-126

Chance B, Maehly AC (1955) Assay of catalases and peroxidases. In: Coloeick SP, Kaplan NO (eds) Methods in enzymology. Academic Press, New York, pp 764-775

Chen M, Ali J, Fu BY, Xu JL, Zhao MF, Jiang YZ, Zhu LH, Shi YY, Yao D, Gao Y, Li Z (2011) Detection of drought-related loci in rice at reproductive stage using selected introgressed lines. Agric Sci China 10(1):1-8

Duan J, Cai W (2012) OsLEA3-2, an abiotic stress induced gene of rice plays a key role in salt and drought tolerance. PLoS One 7(9):e45117. https://doi.org/10. 1371/journal.pone.0045117

Gleick PH, Wolff EL, Chalecki RR (2002) The new economy of water: the risks and benefits of globalization and privatization of fresh water. Pacific Institute for studies in Development, environment and Security, Oakland, p 48 ISBN No. $1-893790-07-X$

Goswami S, Labar R, Paul A, Adak MK, Dey N (2015) Physio-Biochemical and Genetic Exploration for Submergence Tolerance in Rice (Oryza sativa L.) Landraces with Special References to Sub1 Loci. AJPS, 6:1893-1904.

Hwang TY, Sayama T, Takahashi M et al (2009) High-density integrated linkage map based on SSR markers in soybean. DNA Res 16:213-225

ICRISAT-WWF Project (2009) SRI Fact Sheet, International Crops Research Institute for Semi-Arid Tropics. India

Kamoshita A, Babu RC, Boopathi NM, Fukai S (2008) Phenotypic and genotypic analysis of drought-resistance traits for development of rice cultivars adapted to rainfed environments. Field Crop Res 109:1-23

Kar M, Mishra D (1976) Catalase, peroxidase, and polyphenoloxidase activities during rice leaf senescence. Plant Physiol 57:315-319

Lang NT, Nha CT, Ha PTT, Buu BCC (2013) Quantitative trait loci (qtls) associated with drought tolerance in rice (Oryza sativa L.). SABRAO J Breed Genet 45(3):409-421 
Lin MH, Lin CW, Chen J, Lin Y, Cheng S, Liu T, Jan F, Wu S, Thseng F, Ku H (2007) Tagging Rice drought-related QTL with SSR DNA markers. Crop Environment Bioinfo 4:65-76

Nakano Y, Asada K (1981) Hydrogen peroxide is scavenged by ascorbate-specific peroxidase in spinach chloroplasts. Plant Cell Physiol 22:867-880

Noorzuraini ARS, Borromeo TH, Nestor NC, Diaz GM, Arvind K (2013) Diversity assessment of Malaysian rice germplasm accessions for drought tolerant grain yield QTLs. J Trop Agric Fd Sc 41(1):27-40

Roychowdhury R, Karmakar J, Dey N (2012) PCR-compatible genomic DNA isolation from different tissues of rice (Oryza sativa) for SSR fingerprinting. EurAsian J BioSci 6:85-90

Snell FD, Snell CT (1971) In Colorimetric methods of analysis—Van Nostard Reinford Co., New York

Talcott ST, Howard LR (1999) Phenolic autoxidation is responsible for color degradation in processed carrot puree. J Agric Food Chem 47:2109-2115

Tuong TP, Bouman BAM (2003) Rice production in water-scarce environments. International Rice Research Institute, Manila

\section{Submit your manuscript to a SpringerOpen ${ }^{\circ}$ journal and benefit from:}

- Convenient online submission

- Rigorous peer review

- Open access: articles freely available online

- High visibility within the field

Retaining the copyright to your article

Submit your next manuscript at $\boldsymbol{\triangleright}$ springeropen.com 